\title{
The Effect of Service Quality and Customer Satisfaction on Patient Loyalty of Prof. Dr. Moestopo (Beragama) Oral and Dental Hospital
}

\author{
Yulia Rachma Wijayanti ${ }^{1}$ \\ \{yuliarachma@dsn.moestopo.ac.id ${ }^{1}$ \} \\ ${ }^{1}$ Faculty of Dentistry Prof Dr Moestopo (Beragama) University. Jl Bintaro Permai Raya 3, \\ Jakarta Selatan. Indonesia
}

\begin{abstract}
This study aims to determine the effect of service quality and customer satisfaction on patient loyalty of Prof. Dr. Moestopo (Beragama) Oral and Dental Hospital. This research was conducted using descriptive and verification methods. Samples were taken using the non probability sampling technique. The research data collection instrument used questionnaires and library study activities. Regression analysis and SPSS computer software were used to measure how much influence X1, X2, and Y with a total sample of 99 people. The result of this study was there is an influence between service quality variables (X1) and customer satisfaction (X2) on patient loyalty variable $(\mathrm{Y})$ indicated by simple linear regression equation: $\hat{\mathrm{Y}}=-0.342+0.387 \mathrm{X} 1+$ $0.253 \mathrm{X} 2$.
\end{abstract}

Keywords: Service Quality, Customer Satisfaction, Patient Loyalty

\section{Introduction}

Nowadays, health problems have become the main needs for the community. Along with the increasing standard of the people, the demands of the community for health values have also increased. This makes various companies engaged in the health sector face intense competition. Increasing the intensity of competition and the number of competitors requires companies to always pay attention to the needs and desires of consumers and try to meet consumer expectations by providing more satisfying services than those carried out by competitors. Thus, only the best quality companies can compete and dominate the market. A good quality provides an incentive for customers to bond strong relationships with the company. In the long run, this bond allows companies to understand carefully the expectations of customers and their needs.

Hospital is one of the institutions engaged in health services with the responsibility of providing treatment, care, strive for healing and health of patients, and seek education for healthy living for the community. The definition of hospital according to the Minister of Health of the Republic of Indonesia Number 34O/MENKES/PER/M/2010, is a health service that provides inpatient, outpatient, and emergency services. Hospital must be able to provide health services for all types and types of diseases. Outpatient installation provides health services by making health promotion through counseling, making early diagnose, immediate care, and managing strong theraphy, as well as conducting referral services [8].

Consumers have their own judgments on the quality of hospital services which are important as a reference in improving services thus creating of customer satisfaction and 
creating loyalty from consumers. Customer satisfaction has become a central concept in business and management discourse (Tjiptono and Chandra, 2005:192). Customers generally expect products in the form of goods or services consumed to be accepted and enjoyed by good or satisfying services (Assauri, 2003:28). Customers satisfaction can shape perceptions and then positioning the company's products in the eyes of its customers $[1,10]$.

Quality of service is an important thing to note as it will be perceived by consumer after consumer consuming goods/services. The increasingly fierce competition has demanded a service provider to always pamper consumers by providing the best service. Customers will look for products in the form of goods or services and companies that can provide the best service to them (Assauri, 2003:25). If consumers are satisfied with the experience of consuming goods or services, this is the first step to make them as a loyal customer.

Loyalty is an important thing for every company to build to win the competition. Reicheld and Sasser in Suhartanto (2000:5), suggest that a 5\% increase in customer loyalty can increase profits by $25 \%$ to $85 \%$, and $60 \%$ increase in sales to new consumers is on the recommendation of customers loyal to the company. Loyalty is one of the keys to success in winning business competition [9].

Prof. Dr. Moestopo (Beragama) Oral and Dental Hospital (RSGM) has eight laboratories for dental and oral patient services. The laboratories are Pedodontics, Periodontics, Orthodontics, Prosthodontics, Oral Medicine, X-rays, Conservation and Oral Surgery. Prof. Dr. Moestopo (Beragama) Oral and Dental Hospital (RSGM) strives to always maintain consumers trust by improving service quality so that customers satisfaction increases and it is necessary to carefully determine consumers needs as an effort to fulfill desires and increase satisfaction with the services provided. Based on data on the number of Prof. Dr. Moestopo (Beragama) Oral and Dental Hospital (RSGM), the number of patients still fluctuating. This shows a change in both the increase and decrease in the number of patients, the first-time patients as well as the old patients at Prof. Dr. Moestopo (Beragama) Oral and Dental Hospital (RSGM). This shows that Prof. Dr. Moestopo (Beragama) Oral and Dental Hospital (RSGM) still faces several problems, one of which is in terms of the number of patients who are being taken care of. Hospitals are increasingly trying to compete through the services provided and also the price of care so that patients are more selective. Patients who are satisfied will provide an opportunity for the hospital to be re-elected by patients to get the health services. Patient loyalty is an important factor to win the competition. Through the observation that there is a decrease in the number of patients mentioned above, several problems have been found,for example: service is not satisfactory, the waiting time for services is quite long and the satisfaction of the community/patient is very low which is indicated by many complaints. The facts and descriptions above motivated a research on "The Effect of Service Quality and Customer Satisfaction on Patient Loyalty of Prof. Dr. Moestopo (Beragama) Oral and Dental Hospital (RSGM)."

\section{Literature review}

Service quality can be defined as how far the difference between reality and customer expectations for services they receive or obtain (Parasuraman et al. 1998). Quality of service is a thing that must be done by the company in order to be able to survive and still gain customers trust [7]. The consumption patterns and lifestyle of customers require companies to be able to provide quality services. The success of the company in providing quality services can be determined by the service quality approach (Lupiyoadi, 2006:181). Service quality is mentioned as the difference between the expectations and realities of the customers for the 
services they have received [6]. Service quality can be known by comparing customer perceptions of the services they actually receive with the actual service they expect. According to Wyckof (Wisnalmawati, 2005:155), service qualityis the expected level of excellence and control over the level of excellence to meet customer desires [12]. If the services received are as expected, the quality of services is perceived as good and satisfying. If services received exceed customer expectations, then the quality of services is perceived as ideal. Conversely, if the services received are lower than expected, then the quality of services is considered bad (Tjiptono, 2005:121). Referring to the definition of service quality, the concept of service quality is a responsiveness and reality of the services provided by the company [10].

Service quality must begin with customer needs and end with customer perceptions, according to Wisnalmawati $(2005: 156)$. This means that good quality is not based on service provision perception, but based on customer perception [12]. Based on the opinions of experts regarding the definition of service quality variables, also theoretical and conceptual studies, a construct can be drawn up regarding service quality variables defined as service standards that have been standardized as guidelines in service delivery. Based on the conceptual definition, the service standards are: 1) Physical evidence (tangible), with regard to the physical appearance of facilities and infrastructure services, communication devices and personnel displays; 2) Empathy, means that the company understands customer problems and gives personal attention to customers; 3) Responsiveness, with regard to the willingness and ability of service providers to help customers and respond to their requests immediately; 4) Reliability, related to the ability of companies to deliver accurate and consistent services to customers; 5) Assurance.

According to Kotler, satisfaction is the feeling of being happy or disappointed that appears after comparing the performance of products (Kotler et al., 2007:177). According to Lupiyoadi, (2006:54) customer satisfaction or dissatisfaction is the customer's response to the evaluation of the perceived incompatibility between the previous expectations and the actual performance of the product that is felt after its use $[4,6]$. Customer satisfaction is the response of customers to the mismatch between the level of prior importance and the actual performance that they feel. Customer satisfaction is one of the keys to achieve success of a business, this is because by satisfying patients or customers, companies can increase revenue (profit) and gain a wider market share. Customer satisfaction is the level of one's feelings after comparing the performance (or results) that is felt with his expectations. Thus it can be interpreted that customer satisfaction is the difference between the expected customer (expectation value) and the situation given by the company in an effort to meet customer expectations. According to Engel et al. (in Tjiptono, 2000:126), customer satisfaction is "a full-time evaluation where alternatives are chosen at least provide results (outcomes) that are the same or exceed customer expectations, while dissatisfaction will arise if the results obtained do not meet customer expectations" [11]. Customer satisfaction is defined as fulltime evaluation, and perceptions of the performance of selected product/service alternatives meet or exceed expectations before purchase. Customer satisfaction is viewed from the customer side, which is about what customers have felt for the services provided compared to what they want. Customers will be satisfied if the customer's wishes have been fulfilled by the company as expected. With the added value of a product, the customer becomes more satisfied and the possibility to become a customer of a product for a long time will be very large. Therefore, maintaining customers is also an important thing to do. The key to maintaining customers is to provide high customer satisfaction. Satisfied customers will be willing to come back to repeat the purchase and recommend to others to buy. The priority indicator of patient health satisfaction according to the patient is the main aspect that becomes an important 
guideline or measure of size, which is weighty, or which should be related to the implementation of health services that are part of the experience or perceived by the patient.

In general, patient loyalty can be interpreted as someone's loyalty to a product, both certain goods, and services. There are several definitions of loyalty according to experts, including loyalty. Loyalty is defined as non-random purchase expressed over time by some decision-making unit. Based on the definition, it can be seen that loyalty is aimed more at a behavior that is indicated by routine purchases, based on the decision-making unit.

Loyalty is a manifestation of the fundamental needs of humans to belong, support, get a sense of security and build attachment and creates an emotional attachment. Customer loyalty is a repurchase made by a customer because of a commitment to a brand or company. Each patient has a different loyalty base, this depends on their respective objectivity. Understanding loyal customers according to Griffin (2003) is a loyal customer is one who makes regular repeat purchases, purchases across product and service lines, referring others and demonstrates immunity to the attraction of the competition [2]. This means that the characteristics of loyal customers are that they will repeatedly buy products or use services in the same company, continue to use products or services even though there are offers of products or services from other companies, and participate in promoting to others about satisfaction obtained because of using the product or service from that company. Loyalty leads to behavior proposed with routine purchases based on decision-making units. Characteristics of purchase that are loyal are as follows; make repeated purchases regularly, buy between product lines and services, refer to others and show immunity to attraction from competitors.

To become a loyal customer, someone must go through several stages and long time process, with different emphasis and attention for each, because each stage has different needs, by paying attention to each stage and meeting the needs of each stage. Companies have greater opportunities to form prospective customers into loyal customers and corporate clients. Customer loyalty cannot just be created, but it must be designed by the company. The ultimate goal of the company's success in establishing relations with its customers is to form strong loyalty. Indicators of loyalty are as follows; "Say positive things" is saying positive things about the product that has been consumed, "Recommend friend" is recommending the product that has been consumed to a friend, and "Continues purchasing" is a continuous purchase of the product that has been consumed. Indicators in consumer loyalty or patients, such as: make purchases repeatedly; recommend to others; and not affected by other products. The indicator of customer loyalty according to Kotler (2012) is repeat purchase (loyalty to product purchases), retention (resistance to negative influences about the company), and referrals (referring in total to the company's existence). Customer loyalty is the commitment of customers to a product to buy repeatedly continuously [5].

\section{Material and Methods}

The method in this research was descriptive and verification method. Samples were taken using the non probability sampling technique. The research data collection instrument used questionnaires and library study activities. Measurement of how much influence the quality of service (X1), customer satisfaction (X2), on patient loyalty (Y) used regression analysis and SPSS computer software with a total sample of 99 people. Objective data was obtained using research instruments for patient loyalty (Y), service quality (X1), and customer satisfaction (X2) variables. The instrument for patient loyalty variable (Y) was 9 items, service quality instrument (X1) was 11 items, and the instrument for customer satisfaction variable (X2) was 15 items. A total of 99 respondents have responded to the statement given in the form of a 
questionnaire, both for patient loyalty variables (Y), service quality (X1) and for customer satisfaction variables (X2). This research was conducted to provide an overview of the basic measurement of each variable. Measurement of research variables was done through a Likert Scale of data in the form of an ordinal scale. Through the Likert Scale, each research variable can be expressed in a certain size, and more important is that the size can be quantified. Each new response or attitude towards a particular object was given a continuum scale starting from score 1 to score 5 . These scores as a measuring scale that represented responses or attitudes that are "strongly disagree" with a weight score of 1, "disagree" with a score of 2, "neutral" with a score of 3 , "agree" a score of 4 , until "strongly agree" with a score of 5.

\section{Result}

\section{a. The Effect of Service Quality (X1) on Patient Loyalty (Y).}

The characteristic of the relationship or strength of relationship between service quality (X1) and patient loyalty variable (Y) was shown by a positive correlation coefficient (rxy = 0.599). Meaning testing of the tcount correlation coefficient $(7.359)>$ tcriteria $(98 ; 1 ; 97)$ (1.660). The correlation coefficient (rxy), therefore, was significant. The contribution of service quality variables $(\mathrm{X} 1)$ to patient loyalty variables $(\mathrm{Y})$ was indicated by the coefficient of determination $\left(\mathrm{rxy}^{2}\right)$ of $0.358=35.8 \%$. This shows that $35.8 \%$ of the variance in patient loyalty variables (Y) can be determined by service quality variables (X1), and the rest (= $64.2 \%$ ), explained by other variables that cannot be explained in this study. The influence of service quality variables $(\mathrm{X} 1)$ on the variable patient loyalty $(\mathrm{Y})$, indicated by the linear regression equation: $\hat{\mathrm{Y}}=1.660+0.607 \mathrm{X} 1$. Tests for regression significance indicated that Fcount $(54.150)>$ Fcriteria $(98 ; 1 ; 97)(=3.09)$. Regression equation means significant. Regression linearity testing showed that Fcount $(0.842)<$ Fcriteria $(98 ; 14 ; 83)(=3.09)$. The regression equation was linear. The effect shown by the regression equation $\hat{Y}=1.660+$ $0.607 \mathrm{X} 1$. Based on these two tests, the results were meaningful and linear. The simple linear regression equation reflected that each increase in 1 score of service quality variable (X1) will affect the increase in patient loyalty variable $(Y)$ of 0.607 in a constant of 1.660 .

\section{b. The Effect of Customer Satisfaction (X2) on Patient Loyalty (Y).}

The characteristic of relationship or strength of relationship between customer satisfaction (X2) and patient loyalty variable (Y) was indicated by a positive correlation coefficient ( $\mathrm{rxy}=$ 0.656). Meaning testing of the tcount correlation coefficient $(8.563)>$ tcriteria $(98 ; 1 ; 97)$ (1.660). The correlation coefficient (rxy) was significant. Customer satisfaction variable contribution (X2) to patient loyalty variable (Y) was indicated by the coefficient of determination $\left(\mathrm{rxy}^{2}\right)$ of $0.431=43.1 \%$. This means that $43.1 \%$ of the variance of patient loyalty variables (Y) can be explained by the variable customer satisfaction (X2), and the rest $(=56.9 \%)$, explained by other variables that cannot be explained in this study. The influence of the variable customer satisfaction (X2) on the variable patient loyalty (Y), indicated by the linear regression equation: $\hat{\mathrm{Y}}=12.147+0.342 \mathrm{X} 2$. Tests for regression significance indicate that Fcount $(73.330)>$ Fcriteria $(98 ; 1 ; 97)(=3.09)$. The regression equation, therefore, is significant. Linear regression testing shows that Fcount $(0.693)<$ Fcriteria $(98 ; 29 ; 68)(=3.09)$. The regression equation shows linear. The effect shown by the regression equation $\hat{Y}=12.147$ $+0.342 \mathrm{X} 2$. Based on these two tests, the result was meaningful and linear. The simple linear regression equation reflected that each increase in 1 score of customer satisfaction variable (X2) will affect the increase in the patient loyalty variable (Y) of 0.342 in the constant of 12.147 . 


\section{c. The Effect of Service Quality (X1) and Customer Satisfaction (X2) on Patient Loyalty (Y).}

The characteristic of the relationship or strength of the relationship between service quality (X1) and customer satisfaction (X2) with variable patient loyalty (Y) was indicated by a positive correlation coefficient ( $\mathrm{rxy}=0.740$ ). Meaning test of Fcount correlation coefficient $(57.985)>$ Fcriteria $(98 ; 2 ; 96)(=3.09)$. The correlation coefficient (rxy), therefore, means significant. The contribution of service quality variables (X1) and customer satisfaction (X2) to patient loyalty variables $(\mathrm{Y})$ was shown by the coefficient of determination $\left(\mathrm{rxy}^{2}\right)$ of 0.547 $=54.7 \%$. This means that $54.7 \%$ of the variance of patient loyalty variables $(\mathrm{Y})$ can be explained by service quality variables (X1) and customer satisfaction variables (X2) and the rest $(=45.3 \%)$, explained by other variables that cannot be explained in this research.

The influence between service quality variables (X1) and customer satisfaction variables (X2) together with the patient loyalty variable $(\mathrm{Y})$, is indicated by the linear regression equation: $\hat{\mathrm{Y}}=-0.342+0.387 \mathrm{X} 1+0,253 \mathrm{X} 2$. Tests for regression significance show that Fcount $(57.985)>\mathrm{F}$ criteria $(98 ; 2 ; 96)(=3.09)$. The regression equation, therefore, was very significant. The effect shown by the regression equation $\hat{Y}=-0.342+0.387 \mathrm{X} 1+0,253 \mathrm{X} 2$. Based on the test, it means that the regression equation reflected in each 1 score increase of service quality variable (X1) and customer satisfaction variable (X2) will affect the increase in patient loyalty $(\mathrm{Y})$ of 0.387 of service quality and 0.253 of customer satisfaction in a constant of -0.342 .

\section{Conclusion}

The result showed that service quality variables (X1) has an effect on patient loyalty (Y). If you want to increase patient loyalty, it can be done by improving service quality. The level of strength of the relationship between service quality and patient loyalty is very strong. The role of service quality in contributing as much as $35.8 \%$ on patient loyalty. Variable customer satisfaction (X2) influences patient loyalty (Y). If you want to increase patient loyalty, it can be done by increasing customer satisfaction. The level of strength of the relationship between customer satisfaction and patient loyalty is very strong. The role of customer satisfaction in contributing as much as $43.1 \%$ on patient loyalty. Service quality variable (X1) and Customer Satisfaction Variable (X2) affect patient loyalty (Y). If you want to increase patient loyalty, it can be done by improving service quality and customer satisfaction. The level of strength of the relationship between service quality and sustomer satisfaction with patient loyalty is very strong. The role of service quality and customer satisfaction contributing as much as $54.7 \%$ to patient loyalty.

\section{References}

[1] Assauri, Sofjan 2003 Customer Service Yang baik Landasan Pencapaian Customer Satisfaction Usahawan, No.01, Tahun XXXII, Januari, hal.28: Jakarta hal 25-30

[2] Griffin, Jill 2003 Customer loyalty: Menumbuhkan dan Mempertahankan Kesetiaan Pelanggan Jakarta: Erlangga Kottler, Philip and kevin lane keller.

[3] Hurriyati, Ratih 2008 Bauran Pemasaran, dan Loyalitas Konsumen Bandung: Cv.Alfabeta

[4] Kottler, Philip and kevin lane keller 2007 Manajemen pemasaran Edisi kedua belas jilid 1. Jakarta: Indeks 
[5] Kottler, Philip and kevin lane keller 2012 Marketing management Edisi 14 Global Edition Pearson Prentice hall.

[6] Lupiyoadi, Hamdani 2006 Manajemen Pemasaran Jasa Edisi Kedua Jakarta Penerbit Salemba Empat.

[7] Parasuraman, A.,Valerie A.Zeithaml and Leonard L. Berry 1988 Servqual: A multiple Item Scale for meansuring consumer perceptions of service quality Journal of retailing vol.64 No.1

[8] Peraturan Menteri Kesehatan Republik Indonesia Nomor 340/ Menkes/ PER/ III/ 2010. Tentang Klasifikasi Rumah Sakit.

[9] Suhartanto 2000 Analisa Hubungan Antara Kepuasan Konsumen, Citra Hotel dan Hubungan Pribadi Dengan Kesetiaan Pelanggan di Industri Perhotelan : Jakarta

[10] Tjiptono, Fandy dan Gregorius Candra 2005 Service, Quality, and Satisfaction Yogyakarta: Andi Offset.

[11] Tjiptono, Fandy 2000 Prinsip dan Dinamika Pemasaran Edisi pertama Yogyakarta J \& J learning Hal 126

[12] Wisnalmawati 2005 Pengaruh Persepsi Dimensi Kualitas Layanan Terhadap Niat Pembelian Ulang Yogyakarta. 